\section{Afghan Lecturers' Perception of Problem-Based Learning: A Case Study of Takhar University}

\author{
Sayeed Naqibullah Orfan, Sayeed Asif Akramy, Abdul Qawi Noori, \\ Aminuddin Hashemi
}

Department of English, Takhar University, Taleqan, Afghanistan

The study investigated the lecturers' perceptions of problem-based learning (PBL); their attitudes towards PBL, their views of effects of PBL on the learning process and the factors for not employing PBL in their courses. A survey questionnaire was used to collect data from 40 randomly selected lecturers from Takhar University. Descriptive and inferential statistics were used to analyze the data. The findings showed that lecturers had strong positive attitudes towards PBL and they were interested in utilizing PBL in their teaching activities. They were aware of the effects of PBL on the learning process particularly students' learning. They believed that PBL could help students develop a variety of generic skills, e.g., communication and problem-solving skills, which are necessary for employment. However, most of the participants did not make use of PBL in their courses for various reasons such as large number of students in their classes and lack of appropriate infrastructure. The lecturers' gender, level of education and years of teaching experiences did not have any significant impact on their responses.

Keywords: Problem based learning; Generic skills; Active learning; Teaching methods

\section{INTRODUCTION}

Problem based learning (PBL) is a teaching and learning approach that begins with a problem scenario in which students are required to identify a number of learning topics for further exploration and research. Students work in small groups to explore the solutions for the problem (Savery, 2015). One of the main features of PBL is that it allows and encourages several solutions (Camp et al., 2014). In PBL, students construct meaning through engagement in meaningful activities and interaction with their teachers and peers (Yew \& Gew, 2016). According to Watson (2001), students work together to come up with solutions for problems, which help them acquire knowledge and develop their problem-solving, reasoning, communication and self-assessment skills. PBL creates a learning environment in which teachers coach students' thinking and guide their inquiry, which facilitates their deeper understanding of the subject matter (Torp \& Sage, 2002). Azman \& Shine (2012) argue that PBL lets students acquire an integrated body of knowledge from many different subject areas and it helps them develop their teamwork skills.

Problem-based learning is a student-centered approach in which students take responsibility for their own learning and identify what they need to know in order to better understand and manage the problem presented in the learning event. Furthermore, they need to decide on where to obtain the required data (e.g., books, journals, tutorials, and websites) and evaluate their reliability. This allows students to personalize learning and focus on what is limited in their knowledge and understanding. In addition, learning occurs in small groups. Students work together in small groups to find a solution for a problem or an appropriate response to it

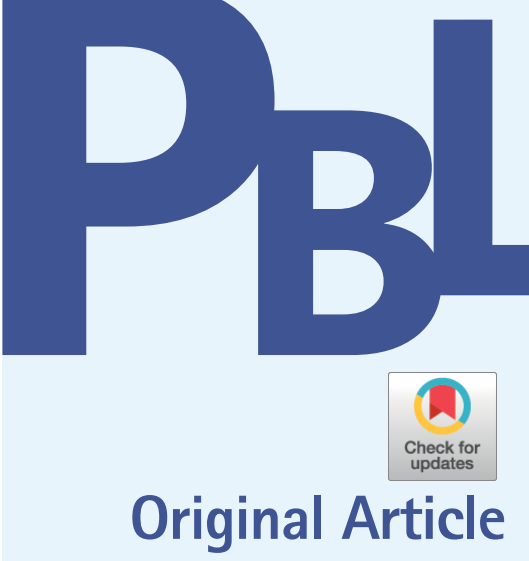

pISSN 2288-8675 · elSSN 2508-9145

J Probl Based Learn 2021;8(2):62-68

https://doi.org/10.24313/jpbl.2021.00059

Received: May 14, 2021

Revised: June 7, 2021 (1st)

July 23, 2021 (2nd)

July 30, 2021 (3rd)

Accepted: August 5, 2021

Corresponding author:

Sayeed Naqibullah Orfan

Department of English, Takhar

University, Taleqan, Afghanistan

Tel: +93-70-321-88-04

E-mail: sayeed.naqibullah@

fulbrightmail.org
(C) Copyright 2021 International Society for Problem-Based Learning

(c) This is an Open Access article distributed under the terms of the Creative Commons Attribution Non-Commercial License (http://creativecommons.org/licenses/ by-nc/4.0/) which permits unrestricted non-commercial use, distribution, and reproduction in any medium, provided the original work is properly cited. 
(Barrows, 1996). In PBL, the teacher acts as a facilitator and she/ he identifies an issue that is interesting, relevant, and new to the students. The problem should be in line with the concepts and the ability of the students, and it should not be so difficult that students cannot solve it nor should it be so easy that it can be solved easily and without research. Another responsibility of the teacher is to place students into groups, supervise their work, and provide them with her/his feedback. Students play a major role. They work together and consider all aspects of the problem until they reach a possible solution. To reach the possible solution, students have to do a series of activities. They narrate, analyze, combine, discuss, think critically, present, actively listen, report, evaluate, and resolve differences among themselves (Kurt, 2020; Papinczak et al., 2007). Hmelo-Silver (2004) asserts that the teachers do not only facilitate students learning but they also ensure that students achieve the intended learning outcomes. Unlike traditional teaching methods, teachers using PBL actively involve students in the learning process and encourage their active participation throughout the learning process (Azer, 2011).

Many studies have shown that PBL is more effective than traditional teaching methods in which teachers are the sole source of learning. Van den Bossche et al (2004) studied the impact of PBL on business education. They divided the participants into two groups. One group was taught using traditional teaching methods, mainly lectures, and the other group was taught through PBL. They gave knowledge and case-based tests to both groups of students to measure the impact of PBL on their learning. The findings showed that students who experienced PBL performed better than those who were taught through lectures. Students who were taught through PBL had a more accessible knowledge base than those who studied in traditional ways. Argaw (2016) investigated students' skills in solving physics problems. The participants were categorized into two groups: PBL and traditional methods. The researcher concluded that students who were taught through PBL had better problem-solving skills than those who were taught through traditional methods. Othman et al. (2016) reported that students who were being taught through PBL were able to present their arguments in a more critical manner in the post test essays and provide sufficient supporting material to illustrate their arguments. Mahmood et al. (2017) found that PBL increased students' motivation and promoted higher order thinking. Katwa et al. (2018) concluded that self-direct learning, which is one of the features of PBL, has helped students become life-long learners. Prince and Felder (2006) reported that PBL fostered students' teamwork skills. Ghimire and Bhandary (2014) reported that the majority of their participants found PBL very useful for improving their generic skills and expressed their interest in having more courses to be delivered through PBL.

Afghan higher education made great strides before the Taliban came to power. The number of girls and women attending higher education rose in the 1980s and they accounted for $40 \%$ of the student body by the early 1990s (Giustozzi, 2010). However, it did not last and it came to almost a standstill when the Taliban rose to power in 1996. They barred girls and women from going to school and universities (Chuang, 2004; Orfan, 2021a; Orfan, 2021b; Noori et al., 2020; Noori \& Orfan, 2021). After the arrival of the international community in Afghanistan in 2001, schools and universities reopened and a growing number of students have been attending schools and universities since then. Conventional teaching approaches and methods that place teachers in the center of the learning process have been prevalent in primary and higher education in Afghanistan.

The Afghan Ministry of Higher Education has taken various initiatives to improve the quality of higher education in the country one of which has been the incorporation of outcome-based education and student-centered learning (OBE-SCL) into higher education. They introduced OBE-SCL to universities in 2015 (Akramy, 2021; Alimyar, 2020). Since then, efforts have been made to institutionalize OBE-SCL in higher education. Training workshops on OBE-SCL are provided for lecturers every year, one component of which is problem-based learning. Due to the heavy load of the workshops and time constraints, enough attention is not paid to problem-based learning. The current study investigates Afghan lecturers' perceptions of problem based learning in Afghan higher education. It studies the lecturers' attitudes towards the use of problem based learning, their perception of the effects of PBL and their reasons for not employing PBL in their courses. Moreover, it explores the impact of the lecturers' gender, level of education and years of teaching experiences on their responses.

\section{METHOD}

\section{Design}

This is a quantitative study, using a survey questionnaire to collect data. The authors used a focus group to identify and develop questionnaire items for the study. They had a discussion with three lecturers about PBL, its effects and factors for not employing the approach at the university. They developed 16 questionnaire items from the focus group discussion. They also carried out a thorough literature review to identify more questionnaire items. They adapted nine questionnaire items from other studies $(\mathrm{Ab}-$ delkarim et al., 2017; Singh et al., 2014; Dube et al., 2014; Ahmed \& Malik, 2013). The questionnaire consisted of four parts. The 
first part sought the respondents' demographic information - gender, level of education and years of teaching experience. The second part consisted of 10 items which aimed to explore the lecturers' attitude towards problem based learning. The third section, composed of 10 statements, elicited the participants' responses about their perception of PBL effects. The last part consisting of five items inquired the participants' response about factors affecting their use of PBL. The participants were required to respond to the items on a five-point Likert scale ( $1=$ strongly disagree, $2=$ disagree, $3=$ undecided, $4=$ agree, $5=$ strongly agree).

Prior to the data collection, the authors gave the questionnaire to three of their colleagues in the English Department to read it for revision and improvement. The problematic items were identified and revised based on their feedback. They conducted a pilot test with seven lecturers to ensure the consistency of the items. As Table 1 shows, the reliability value for each category is over 0.7 , which indicates that the items were appropriate for the study. The authors translated the questionnaire into Dari (the lingua franca of the country) since English is a foreign language in Afghanistan and many people cannot speak English (Orfan, 2020). The Dari questionnaire was given to three lecturers of Dari Department to ensure its comprehensibility.

Table 1. Reliability value of questionnaire items

\begin{tabular}{lcc}
\hline Category & Number of Items & Cronbach's Alpha \\
\hline Attitudes & 10 & 0.742 \\
Effectiveness & 10 & 0.708 \\
Reasons & 5 & 0.781 \\
\hline
\end{tabular}

\section{Procedure and analysis}

The authors collected data from 40 randomly selected lecturers from Takhar University. They presented a copy of the questionnaire along with a consent form to each participant. They explained the research and its purposes to the participants and they were requested to read and sign the consent form if they were willing to participate in the study. The consent form ensured them of the confidentiality of their responses and that their participation was voluntary. The participants were required to read the instruction for each section and complete it accordingly. The researchers encouraged the participants to ask about any vague or ambiguous items. It took the respondents on average 10-15 minutes to complete the questionnaire.

The researchers numerically coded the data in an Excel spread sheet and imported this to SPSS version 26.0 for analysis. They closely examined the completed questionnaires to make sure the participants filled them out appropriately. Three questionnaires were excluded from the analysis since the participants failed to complete them appropriately. The authors conducted descriptive statistics to determine the mean and percentage of the items. They also ran Independent Samples T-test and One-Way ANOVA test to determine the differences between the participants' gender and level of education.

\section{RESULTS}

\section{Participants}

There were 40 participants who were randomly selected from Takhar University for the study. The authors obtained the list of lecturers, who received OBE-SCL training, from the Professional Development Center (PDC) of Takhar University, and 85 lecturers received the training. Out of 85, 27 were not accessible since they were pursuing their higher education (master's degree, doctoral degree) at the time of the study. The authors wrote the names of 58 lecturers and they picked 50 of them after shuffling and reshuffling. They distributed the questionnaire to 50 lecturers; 40 of them returned the completed anonymous questionnaire. The participants were teaching in various faculties of Takhar University: engineering, agriculture, economics, education, language \& literature, sharia and law. Around $20 \%$ of the participants were female while $80 \%$ of them were males. The participants had 1-15 years of teaching experiences at the time of the study. The vast majority of the participants (85\%) held a master's degree while a small fraction of them (15\%) had a bachelor's degree at the time of the study.

\section{Lecturers' attitudes towards PBL}

The authors conducted descriptive statistics to determine the lecturers' attitudes towards problem based learning. As Table 2 shows, the overall mean score for the attitude is 4.08 , which indicates that lecturers have strong positive attitudes towards problem based learning. Furthermore, $90 \%$ of the participants (36) believed that PBL is better than traditional methods, creates interest in topics, makes topics interesting and it is an effective learning method. Over $80 \%$ of the respondents stated that PBL is a student centered and scientific method and that it encourages independent thinking. Moreover, over $70 \%$ of the respondents believed that they were interested in using PBL in their courses and that PBL facilitated interaction and encouraged students to learn in context.

\section{PBL effects}

Descriptive statistics were used to explore the lecturers' perceptions about effects of problem based learning. As Table 3 demon- 
Table 2. Lecturers' attitudes towards PBL

\begin{tabular}{llll}
\hline No & \multicolumn{1}{c}{ Statement } & \% A \& SA & Mean \\
\hline 1 & PBL creates interest in topic. & 95 & 4.23 \\
2 & PBL makes the topic more interesting and fun. & 91.5 & 4.2 \\
3 & PBL is better than a traditional teaching method. & 90.7 & 4.16 \\
4 & PBL is an effective learning method. & 87.5 & 87.5 \\
5 & PBL encourages students' independent thinking. & 81.2 & 4.1 \\
6 & PBL is students centered learning. & 77.5 & 4.18 \\
7 & PBL is more scientific way of teaching. & 75 & 4.05 \\
8 & I am interested in using PBL in my courses. & 72.5 & 3.98 \\
9 & PBL facilitates interaction with peers. & 4.05 \\
10 & PBL encourages students to learn in context. & Overall attitude & 3.98 \\
\end{tabular}

Table 3. Lecturers' perception of PBL effects

\begin{tabular}{llll}
\hline No & \multicolumn{1}{c}{ Statement } & \% A \& SA & Mean \\
\hline 1 & PBL enhances students' understanding of the subject. & 95 & 9.3 \\
2 & PBL facilitates self-learning. & 91.3 & 4.13 \\
3 & PBL increases students' involvement in the learning process. & 87.5 & 4.18 \\
4 & PBL strengthens students intrinsic motivation & 85 & 4.2 \\
5 & PBL improves students' problem solving skills. & 85 & 4.28 \\
6 & PBL helps students to identify their strengths and weaknesses & 85 & 4.05 \\
7 & PBL increases students' participation in the learning activities. & 79 & 4.1 \\
8 & PBL enhances students' teamwork skills. & 77.5 & 3.93 \\
9 & PBL improves students' communication skills. & 72.4 & 4.08 \\
\hline
\end{tabular}

Table 4. Factors affecting PBL at the university

\begin{tabular}{llll}
\hline No & \multicolumn{1}{c}{ Statement } & \% A \& SA & Mean \\
\hline 1 & There is a large number of students in my courses. & 85.6 & 71.3 \\
2 & The infrastructure at the university does not support the use of PBL. & 65 & 3.79 \\
3 & I do not have the required knowledge of applying PBL. & 73.2 & 3.59 \\
4 & PBL is not applicable in my courses. & 57.7 & 3.93 \\
5 & The curriculum does not support the use of PBL. & 3.07 \\
\hline
\end{tabular}

strates, over $90 \%$ of the participants believed that PBL would enhance students' understanding of the subject, facilitate self-learning and increase students' involvement in the learning process. Over $80 \%$ believed that PBL would reinforce students' motivation, improve problem-solving skills, help students identify their strengths and weaknesses and increase students' participation in the learning activities. Furthermore, over $70 \%$ stated that PBL would enhance students' teamwork, communication and critical thinking skills.

\section{Factors affecting the use of PBL at the university}

The last part of the questionnaire sought the participants' response about factors affecting their use of PBL in their courses. As
Table 4 shows, over $70 \%$ of the participants stated that large number of students in classes, lack of appropriate infrastructure and inapplicability of PBL in their courses are the major reasons why lecturers do not use PBL in their courses. Moreover, $65 \%$ of the participants did not have the required knowledge to use PBL in their courses. Around 58\% believed that their curriculum did not allow the use of PBL in their course.

\section{Participants' demographic profile}

The authors conducted Independent Samples $T$-test and OneWay ANOVA test to determine the differences in lecturers' responses by their gender, education level and years of teaching experiences. As Table 5 shows, the p-value for all three variables is 
Table 5. Participants' attitudes by gender, education and teaching experiences

\begin{tabular}{llcccc}
\hline Variables & & N & Mean & SD & $p$-value \\
\hline Gender & Female & 8 & 4.21 & 0.275 & 0.420 \\
& Male & 32 & 4.03 & 0.619 & 0.152 \\
Education Level & Bachelor & 6 & 4.15 & 0.615 & 0.697 \\
Years of teaching experiences & Master & 34 & 4.05 & 0.558 & 0.692 \\
& $1-5$ & 20 & 14 & 4.01 & 0.256 \\
\hline
\end{tabular}

Table 6. Effects of PBL by gender, Education level and experiences

\begin{tabular}{llrccc}
\hline Variables & & $N$ & Mean & SD & $p$-value \\
\hline Gender & Female & 8 & 4.14 & 0.227 & 0.950 \\
Education Level & Male & 32 & 4.13 & 0.250 & 0.975 \\
& Bachelor & 6 & 4.13 & 0.526 & 0.462 \\
Years of teaching experiences & Master & 34 & 4.13 & 0.620 & 0.842 \\
& $1-5$ & 20 & 14 & 4.06 & 0.235 \\
\hline
\end{tabular}

greater than the alpha level (0.05). Furthermore, the p-value for all three variables with respect to PBL effects are greater than the alpha level (Table 6). Thus, it is concluded that the lecturers' gender, education level and years of teaching experiences did not have any significant impact on their responses.

\section{DISCUSSION}

The study investigated Afghan lecturers' attitudes towards problem based learning, their perceptions of the effects of PBL and issues around not employing PBL at the university. It also examined whether the lecturers' gender, level of education and years of teaching experiences had any significant impact on their responses. The results of the study showed that lecturers had strong positive attitudes towards PBL and the majority of them were interested in utilizing PBL in their teaching and learning activities. The finding is on a par with the results of the study by Ahmed and Malik (2013) and Aboonq (2015) who reported that their participants had strong perceptions towards the use of PBL.

The results also showed that lecturers were aware of the effects of PBL in the learning process particularly on students' learning. The vast majority of them believed that PBL would enhance a wide range of students' generic skills, which are considered necessary for employment after graduation. They believed that PBL would improve students' team work, communication, critical thinking and problem-solving skills. Furthermore, they believed that PBL would increase students' participation and engagement in the learning process and strengthen their motivation for learning. These findings resonate with those of the studies carried out by Abdelkarim et al. (2018) and Aziz et al. (2014) who found that their participants knew the positive impacts of problem based learning on the learning process.

In addition, the findings revealed that lecturers could not employ problem based learning in their teaching and learning activities for various reasons. They did not utilize problem based learning due to a large number of students in their classes and lack of appropriate infrastructure at the university. It can be accounted for by the fact the number of students has been substantially increasing in Afghan higher education and there are too many students in classrooms, for example 150. Lecturers particularly in provincial universities have to teach at least four courses and they have no assistants to help them with course planning, organization and instruction. They have to do everything related to their courses by themselves.

Moreover, the infrastructure in many public universities fails to meet the basic requirements for learning. For instance, classrooms aimed to house 40 students in a session, are used to house $80 \mathrm{stu}-$ dents; this makes it impossible for the lecturers move around the class let alone conduct group activities in the classroom. This finding is similar to that of the study by Hashemi (2021) who reported that less ICT infrastructure in public universities was one of the challenges of conducting online teaching in Afghanistan. Most of the participants could not make use of PBL in their learning and teaching activities because they lacked the knowledge of 
PBL application in their courses. It can also be accounted for by the fact that there are not sufficient capacity building programs for lecturers particularly with regard to modern teaching approaches and methods. In addition, most of the lecturers did not use PBL in their courses because they believed that it was not applicable in their courses. The authors believe that their low level of knowledge about PBL and its principles led the lecturers to believe that the PBL was not applicable in their courses. The lecturers believed that the curriculum did not support the use of PBL. It can be accounted for by the fact that the curriculum obliges the lecturers to teach certain topics by the end of a semester. There were not any statistically significant differences between the lecturers' responses by their gender, level of education and years of teaching experiences.

\section{CONCLUSIONS}

The study revealed that the lecturers had strong positive attitudes towards the use of problem based learning in their teaching and learning activities. They believed that the use of PBL in courses could have positive impacts on the learning process particularly on students' learning and it could improve a wide variety of students' soft skills, for example communication and problem-solving skills which are necessary for employment. The lecturers did not use PBL in their teaching and learning tasks for various reasons, including huge number of students in their courses. The lecturers' gender, level of education and length of teaching experiences did not have a significant impact on their responses.

PBL is one of the most innovating teaching and learning approaches and it has proven to be effective in higher education. Many studies reported that PBL had significant impact on the learning process. More importantly, PBL helps students acquire a wide variety of generic skills such as communication, negotiation and problem-solving, which are deemed necessary for employment after graduation and good performance in the work. Curriculum design needs to be consistent with producing graduate outcomes that is consistent with the needs of contemporary contexts. Therefore, the authors suggest Afghan universities provide the lecturers with training workshops in order to enable them make use of the elements of PBL (student-centered and self-directed learning, processes of enquiry and critical thinking, investigation of real world problems) and incorporate them in their teaching activities in order to boost students' learning and motivation. The study is limited in two ways. It is a case study at one Afghan public university. The sample size is also small and that does not support generalization to all Afghan higher education institutions. Therefore, the authors suggest further studies and they should have a larger sample from various public and private higher education in- stitutions. They should also utilize interviews for data collection.

\section{REFERENCES}

Abdelkarim, A., Schween, D., \& Ford, T. (2018). Attitudes Towards Problem-Based Learning of Faculty Members at 12 US Medical and Dental Schools: A Comparative Study. Journal of dental education, 82(2), 144-151.

Aboonq, M. (2015). Perception of the faculty regarding problem-based learning as an educational approach in Northwestern Saudi Arabia. Saudi medical journal, 36(11), 1329-1335.

Ahmed, Z.., \& Malik, S. K.. (2013). Perception of University Teachers about Initiation of Problem Based Learning (PBL) at University Level. lixir Edu. Tech, 54, 12425-12430.

Akramy, S. A. (2021). Implementation of outcome-based education (obe) in Afghan universities: Lecturers' voices. International Journal of Quality in Education, 5(2), 27-47.

Alimyar, Z. (2020). Outcome-based education training workshops: A study to explore their effectiveness on Afghan EFL instructors' teaching methods. International Journal of Education and Culture, 9(1-2), 18-30.

Argaw, A. S., Haile, B. B., Ayalew, B. T., \& Kuma, S. G. (2016). The effect of problem based learning (PBL) instruction on students' motivation and problem solving skills of physics. Eurasia Journal of Mathematics, Science and Technology Education, 13(3), 857-871.

Azer, S. A. (2011). Introducing a problem-based learning program: 12 tips for success. Medical teacher, 33(10), 808-813.

Aziz, A., Iqbal, S., \& Zaman, A. U. (2014). Problem based learning and its implementation: faculty and student's perception. Journal of Ayub Medical College Abbottabad, 26(4), 496-500. 26

Azman, N., \& Shin, L. K. (2012). Problem-based Learning in English for a Second Language Classroom: Students' Perspectives. International Journal of Learning, 18(6), 109-126.

Barrows, H. S. (1996). Problem-based learning in medicine and beyond: A brief overview. New directions for teaching and learning, 1996(68), 3-12.

Camp, G., van het Kaar, A., van der Molen, H., \& Schmidt, H. (2014). PBL: step by step. The Netherlands. Erasmus University. Chuang, A. (2004). If You Believe in Faith: An Interview with Afghanistan's Minister of Higher Education. Academe, 90(5), 3133.

Dube, S., Ghadlinge, M., Mungal, S.U., Tamboli, S.B.., \& Kulkarni, M. B.. (2014). Students Perception towards Problem Based Learning. IOSR Journal of Dental and Medical Sciences, 13(5), 49-53.

Ghimire, S. R., \& Bhandary, S. (2014). Studentsâ $€^{\mathrm{Tw}}$ Perception 
and Preference of Problem Based Learning During Introductory Course of a Nepalese Medical School. Journal of Patan Academy of Health Sciences, 1(1), 64-68.

Giustozzi, A. (2010). Between Patronage and Rebellion: Student Politics in Afghanistan. Higher Education. Academe, 90(5), 3133.

Hmelo-Silver, C. E. (2004). Problem-based learning: What and how do students learn? Educational psychology review, 16(3), 235-266.

Hashemi, A. (2021). Online teaching experiences in higher education institutions of Afghanistan during the COVID-19 outbreak: Challenges and opportunities. Cogent Arts \& Humanities, 8(1), 1947008.

Katwa, J. K., Obwoge, R. O., Baliddawa, J., Ayiri, L., \& Kei, R. (2018). Knowledge and Perception of Lecturers regarding Problem-Based Learning as an Educational Approach in College of Health Sciences, Moi University. IOSR Journal of Research \& Method in Education (IOSR-JRME) (pp. 26-29.

Kurt, S. (2020). Problem based learning. In Education Technology. Retrieved from https://educationaltechnology.net/ problem-based-learning-pbl/.

Mahmood, S. U., Syed, F., Khan, N. R., Batool, Z., \& Rehman, R. (2017). Comparison of problem based with case based learning: A cross-sectional study. PakJ Physiol, 13(4), 52-6.

Noori, A. Q. Said, H., Nor, F. M., \& Abd Ghani, F. (2020). The Relationship between University Lecturers' Behaviour and Students' Motivation. Universal Journal of Educational Research, 8(11C), 15-22.

Noori, A. Q. \& Orfan, S. N. (2021). The challenges of undergraduate married female students in higher education: A case study of Takhar University. Journal of World Englishes and Educational Practices, 3(6), 09-18.

Orfan, S. N. (2020). Afghan undergraduate students' attitudes towards learning English. Cogent Arts \& Humanities, 7(1), 1723831.

Orfan, S. N. (2021a). Political participation of Afghan Youths on Facebook: A case study of Northeastern Afghanistan. Cogent Social Sciences, 7(1), 1857916.
Orfan, S. N. (2021b). High school English textbooks promote gender inequality in Afghanistan. Pedagogy, Culture \& Society (pp. 1.16.

Othman, A. B., Shah, K. S. H. A., Ibrahim, M. I. B. M., Ridzwan, I. U. B., Mohaiyadin, N. M. B., \& Besi, K. S. (2016). FACTORS contribute towards challenges faced by the students in the implementation of problem based learning ( $\mathrm{pbl}$ ). Journal of Education and Social Sciences, 4, 133-139.

Papinczak, T., Young, L., Groves, M., \& Haynes, M. (2007). An analysis of peer, self, and tutor assessment in problem-based learning tutorials. Medical teacher, 29(5), e122-e132.

Prince, M., \& Felder, R. (2007). The many faces of inductive teaching and learning. Journal of college science teaching, 36(5), 14.

Savery, J. R. (2015). Overview of problem-based learning: Definitions and distinctions. Essential readings in problem-based learning: Exploring and extending the legacy of Howard S. Barrows, 9, 5-15.

Singh, A., Saxena, A., Bhambani, P., Nema, S. K., Gaur, R., \& Ambey, R. (2014). Faculty perception and attitude on Problem Based Learning (PBL) in medical college from central India. Journal of Advances in Medicine and Medical Research, 4(9), 1836-1843.

Torp, L., \& Sage, S. (2002). Problems as Possibilities. Problem-Based Learning for K-12 Education. 2nd Ed. ASCD, Alexandria, VA.

Van den Bossche, P., Segers, M., Gijbels, D.., \& Dochy, F.. (2004). Effects of problem-based learning in business education: a comparison between a PBL and a conventional approach. In R. Ottewill \& (Eds.), Educational Innovation in Economics and Business Volume VIII. Kluwer Academic Publishers, Dordrecht, Netherlands. 205-227.

Watson, G. H. (2001). Problem-based learning and the three Cs of technology. The power of problem-based learning (pp. 109117.

Yew, E. H.J., \& Goh, K.. (2016). Problem based learning: An overview of its process and impact on learning. Health Professions Education. 